\title{
MicroRNAs in ovarian follicular atresia and granulosa cell apoptosis
}

\author{
Jinbi Zhang®, Yinxue Xu, Honglin Liu and Zengxiang Pan ${ }^{*}$
}

\begin{abstract}
MicroRNAs (miRNAs) are short, noncoding RNAs that posttranscriptionally regulate gene expression. In the past decade, studies on miRNAs in ovaries have revealed the key roles of miRNAs in ovarian development and function. In this review, we first introduce the development of follicular atresia research and then summarize genome-wide studies on the ovarian miRNA profiles of different mammalian species. Differentially expressed miRNA profiles during atresia and other biological processes are herein compared. In addition, current knowledge on confirmed functional miRNAs during the follicular atresia process, which is mostly indicated by granulosa cell (GC) apoptosis, is presented. The main miRNA families and clusters, including the let-7 family, miR-23-27-24 cluster, miR-183-96-182 cluster and miR-17-92 cluster, and related pathways that are involved in follicular atresia are thoroughly summarized. A deep understanding of the roles of miRNA networks will not only help elucidate the mechanisms of GC apoptosis, follicular development, atresia and their disorders but also offer new diagnostic and treatment strategies for infertility and other ovarian dysfunctions.
\end{abstract}

Keywords: MicroRNA, Follicular atresia, Granulosa cell apoptosis, Ovary

\section{Background}

Female fertility potential is based on the development and growth of ovarian follicles, and animal breeds with higher fecundity often show larger numbers of mature follicles in their ovaries and a higher ovulation rate than those with lower fecundity. However, the mammalian follicle utilization rate is extremely low because most follicles are removed from the ovaries before ovulation via a degenerative process known as atresia [1,2]. Among domesticated animals, cows and sheep have approximately 1 million follicles, and sows have approximately 5 million primordial follicles in their ovaries at birth. However, more than $95 \%$ of these follicles undergo atresia [3-5]. Of the approximately 2 million primordial follicles that exist in human ovaries at birth, only up to 400 are ovulated throughout a female's lifetime, which means that more than $99 \%$ of the follicles are lost. Therefore, methods to develop and utilize the abundant resources of ovarian follicles are consistently sought in animal reproduction research. Follicular atresia is a complex process that involves multiple regulatory factors, and

\footnotetext{
* Correspondence: owwa@njau.edu.cn

College of Animal Science and Technology, Nanjing Agriculture University, Nanjing 210095, People's Republic of China
}

studies on atresia mechanisms can be summarized in 3 aspects: 1) studies on follicular morphology and biochemistry, 2) studies on regulatory signalling pathways in granulosa cell (GC) apoptosis, and 3) studies on transcriptional/posttranscriptional mechanisms in $\mathrm{GC}$ apoptosis.

In 1987, Moor R et al. were the first to identify morphological changes in the atretic follicles of sheep [6], including the degree of translucency, vascularization of the follicle membrane and integrity of the membrane GC layers. Similar morphological features of isolated follicles were also observed in sows and cows [7, 8]. These features have been continually applied as important classification standards for atresia identification.

Endocrinological quantifications in follicular fluid are also standards for identifying antral follicle atresia. The concentration of oestrogen (E2) and the ratio between E2 and progesterone (P4) indicate a high correlation with the macroscopic classification of atresia. The steroid hormone concentrations detected by the enzyme immune assay (EIA) in medium-sized follicles $(8-10 \mathrm{~mm})$ in bovine follicular fluid suggest a P4/E2 $<1$ in healthy follicles and a P4/E2 $>1$ in atretic follicles. The ratio further drops with the degree of atresia [9]. A study on

C The Author(s). 2019 Open Access This article is distributed under the terms of the Creative Commons Attribution 4.0 International License (http://creativecommons.org/licenses/by/4.0/), which permits unrestricted use, distribution, and 
small $(3-6 \mathrm{~mm})$ and large $(>6 \mathrm{~mm})$ ewe follicles using a nonextraction, solid-phase radioimmunoassay (RIA) suggested the same criteria [10]. In addition, steroid hormone concentrations detected in medium-sized (3-5 $\mathrm{mm})$ pig follicles using RIA suggest a $\mathrm{P} 4 / \mathrm{E} 2<5$ in healthy follicles and a P4/E2 $>5$ in atretic follicles [11]. Based on our experience, a competitive ELISA method can also be used for hormone detection in pigs, and the classification standard is the same as that for RIA. Although the specific ratio varies depending on the species and detection method, all studies agree that higher E2 concentrations and lower P4/E2 levels indicate healthier follicular conditions.

With the development of ovarian studies, researchers have gradually realized that the basic physical mechanism of follicular atresia is GC apoptosis. When atresia occurs, pyknotic nuclei are first observed in GCs, which is followed by detachment of the GC layer and fragmentation of the basal membrane, ultimately resulting in hypertrophied thecal cells and disruption of thecal integration and thecal vessels. Degeneration of oocytes, however, may occur at any stage of atresia. The above phenomenon was first observed in bovine [12] and subsequently reported in chickens [13], rats [14], cows [15], sheep [16] and sows [17]. Therefore, follicular atresia studies have become increasingly focused on the molecular regulation of GC apoptosis. Further studies have shown that GC apoptosis may occur much earlier than the morphological changes in follicular atresia, which can be observed only when GC apoptosis reaches a certain degree $[18,19]$. Generally, proliferation and differentiation of GCs leads to follicular maturation and ovulation, whereas apoptosis and degeneration of GCs results in follicular atresia $[13,20]$.

A considerable number of known molecular factors are involved in the regulation of GC apoptosis, including proapoptotic molecules, such as FAS (Fas cell surface death receptor), CASPs (caspases), MYC (MYC proto-oncogene BHLH transcription factor), TNF (tumour necrosis factor), F2RL3 (F2R-like thrombin or trypsin receptor 3, Par4) and PHB (prohibitin), as well as molecules that promote cell survival, such as activin, KITLG (KIT ligand, SCF), IFN (interferon), EDNs (endothelins), TP53 (tumour protein P53)b and NOBOX (newborn ovary homeobox-encoding gene) [21-24]. Although new regulatory factors are continuously being identified, comprehensive knowledge of the signalling networks that function during GC apoptosis remains limited.

In recent decades, the rapid rise of posttranscriptional mechanistic studies, especially miRNA studies, has brought a new perspective to reproductive system research. miRNAs comprise a broad class of endogenous, short, noncoding single-stranded RNA molecules that are normally $18-24 \mathrm{nt}$ in length. Like mRNAs, miRNAs are originally transcribed from coding genes that are hundreds of kilobases long and occupy 1-3\% of the genome [25]. miRNA-coding genes are distributed across chromosomes either individually or in clusters in which two or more miRNA genes are located within a short distance on the same segment of a chromosome. Thus, miRNA clusters on a given segment usually show a synergetic transcription pattern and related regulatory functions [26]. Based on gene structure, pri-miRNAs can be classified into three broad categories: Class I pri-miRNAs are transcribed independently of other genes, Class II pri-miRNAs are transcribed as an extension of a protein-coding gene, and Class III pri-miRNAs are transcribed as an extension of a noncoding RNA [27]. However, pri-miRNAs are poorly detected by standard methods, such as RT-PCR and RNA sequencing, due to rapid recognition and processing by the microprocessor complex, an enzyme arrangement made up of one Drosha protein and two DGCR8 proteins [28], resulting in 70-90 nt precursor miRNAs (pre-miRNAs) with hairpin structures. The pre-miRNAs are then transferred into the cytoplasm, and after further processing by Dicer, a cytosolic RNase III-type endonuclease, 18-24 nt double-stranded miRNAs are generated. With the elimination of one strand, the final single-stranded mature miRNA is loaded into an Argonaute (AGO) protein to form the miRNA-induced silencing complex (miRISC, RISC), which binds to specific sequences on target mRNAs, specifically to their 3 '-untranslated regions ( 3 '-UTRs), and results in either target mRNA degradation [29] or target mRNA transcriptional repression [30]. The estimation that nearly all mature sequences of coding mRNA transcripts contain miRNA response elements (MREs) implies crucial roles of miRNAs in almost all biological contexts during developmental, physiological and pathological processes. It is notable that one miRNA can regulate more than one gene, and conversely, a single gene can be regulated by multiple miRNAs [31].

In mammalian ovaries, folliculogenesis and atresia processes are tightly regulated by a complex network of genes. Therefore, miRNAs, which can originate from both cellular and extracellular sources, function as mediators of these processes via their extensive involvement in posttranscriptional mRNA regulation. The roles of ovarian miRNAs have been summarized in previous reviews on follicular and luteal development [32, 33], ovarian function [3, 34-36], and ovarian diseases and disorders [37-39]. Thus, this review primarily focuses on the latest findings concerning the roles of miRNAs in follicular atresia and $\mathrm{GC}$ apoptosis. 


\section{Profile studies reveal specific shifts in miRNAs during atresia and other ovarian processes}

Studies on ovarian miRNAs in humans, mice, cows, sows, sheep and goats have gradually assembled specific profiles of miRNA transcription in mammalian ovarian tissues. Ovarian miRNA profiles were also reported in studies on the reproduction of poultry animals, such as chicken [40] and geese [41]. High-throughput miRNA profiling studies have provided valuable references for deeply understanding the molecular mechanisms in ovarian tissue. Herein, we list the mammalian ovarian miRNA profiles that have been identified in whole ovaries, isolated follicles, or certain parts of follicles, including extracellular vesicles (EV) in follicular fluid, during various physiological and pathological processes (Table 1).

These studies applied microRNA sequencing, microarray or PCR array methods and provided useful candidates for further studies, which may lead to the identification of biomarkers for medical diagnosis in ovarian disorders. To gain a general view of miRNA functions in ovaries, we generated 2 cloud charts (Fig. 1) based on previously performed high-throughput studies by simply integrating the results of research on 1) miRNAs differentially expressed during follicular atresia [42, 43] and 2) miRNAs differentially expressed among small, mediumsized and large follicles [43-48]. Clearly, miRNAs that are involved in different biological processes are remarkably divergent in the ovary. Among the most notable miRNAs that changed during atresia, miR-1275, which is known to regulate insulin-like growth factor-2 mRNA-binding proteins (IGF2BP1, IGF2BP2 and IGF2BP3) in cancer [49], was recently shown to affect E2 synthesis and lead to GC apoptosis by targeting liver receptor homologue (LRH)-1 [50]. In addition, although not yet related to ovarian atresia, miR-1826 was reported to regulate $\beta$-catenin (CTN NB1) by the observance of direct binding in cancer studies [51], while miR-190a was shown to mediate VEGF [52] and oestrogen receptor (ER)-related signalling in angiogenesis [53], and miR-210 was proven to be related to hypoxia $[54,55]$. It is clear that high-frequency miRNAs are connected to atresia-related pathways and can thus be considered helpful hits in follicular atresia and cell apoptosis-related studies.

\section{Specific miRNAs and their functions in follicular atresia and GC apoptosis}

To explore the effective functions of miRNAs during atresia, gain- and loss-of-function studies have been applied by researchers in vitro. A list summarizing known studies on miRNAs directly or indirectly involved in GC proliferation and apoptosis is presented in Table 2, which includes combinations of miRNAs, their verified target genes and miRNA functions. The list will certainly continue to grow with contributions from research on this topic. Here, we attempt to summarize several main families and groups of miRNAs that play critical roles in $\mathrm{GC}$ apoptosis and the follicular atresia process.

\section{Let-7 family in follicular atresia}

The let-7 family is one of the first discovered miRNA groups, and its family members are highly conserved in sequences across animal species [56]. The functions of let-7 family members include cell proliferation, differentiation, tissue development and tumour suppression [57]. Both microarray and RT-qPCR analyses have shown that members of the let-7 family are differentially expressed during porcine follicular atresia. For example, the expression levels of let-7a, let-7b, let-7c, and let-7i were decreased in early and progressed atretic follicles compared to those in healthy follicles $[58,59]$. Downregulation of let-7c was also detected in premature ovarian failure (POF) patients compared to that in normal women [60], which implied that let-7c plays a positive role in healthy follicular development. The function of let7-g in follicles appears to be different from that of other family members because it is highly expressed during atresia [59]. Further studies have identified the anti-apoptotic genes MAP3K1 (mitogen-activated protein kinase kinase kinase 1 ) and TGFBR1 (transforming growth factor- $\beta$ type 1 receptor) as direct targets of let- $7 \mathrm{~g}$. The let- $7 \mathrm{~g}$-mediated suppression of MAP3K1 results in the expression and dephosphorylation of the transcription factor FoxO1 (forkhead box O1), which accumulates in the nucleus and induces GC apoptosis [61]. Furthermore, a let-7 g-induced blockage of TGFBR1 increases caspase- 3 activity and the apoptosis rate due to suppression of the TGF $\beta$ signalling pathway. In addition, let-7 $\mathrm{g}$ may function as a potent antagonist that regulates the same pathways as let- $7 \mathrm{a} / \mathrm{b} / \mathrm{c} / \mathrm{I}$, which makes the let-7 miRNA family a bidirectional regulatory network during GC apoptosis [58]. In brief, the let-7 miRNA family shows great potential in the regulation of follicular atresia; the detailed mechanisms await further validation.

\section{TGF $\beta / S M A D$ signalling and the miR-17-92 cluster in}

\section{follicular atresia}

The TGF $\beta$ signalling pathway has a wide spectrum of functions that depend on specific biological contexts. Generally, TGF $\beta$ ligands (TGFB1, TGFB2, and TGFB3) first activate a membrane receptor serine/threonine kinase complex composed of type II (TGFBR2) and type I (TGFBR1) receptors. After phosphorylation by TGFBR1, SMAD2/3 forms an oligomeric complex with SMAD4 and translocates to the nucleus, where it can either promote or inhibit the transcription of target genes [62]. In follicular studies, the roles of the TGF $\beta$ pathway and related miRNA regulation have been frequently reported 
Table 1 miRNA profile studies carried out in mammalian ovaries

\begin{tabular}{|c|c|c|c|c|}
\hline Tissue & Species & Description & Method & Reference \\
\hline \multirow[t]{12}{*}{ Ovary } & bovine & foetal ovary & miRNA seq & [95] \\
\hline & sheep & $\begin{array}{l}\text { early/mid-gestational foetal } \\
\text { ovary }\end{array}$ & PCR array & [96] \\
\hline & mouse & newborn ovary & small RNA seq & [97] \\
\hline & mouse & newborn ovary & microarray & [46] \\
\hline & mouse & 2-week-old/adult ovary & small RNA seq & {$[98]$} \\
\hline & mouse & adult ovary & small RNA seq & [99] \\
\hline & bovine & adult ovary & miRNA seq & {$[100]$} \\
\hline & bovine & $\begin{array}{l}\text { adult testicular and ovarian } \\
\text { tissues of Holstein cattle }\end{array}$ & miRNA seq & {$[101]$} \\
\hline & porcine & adult ovary and testis & miRNA seq & [102] \\
\hline & sheep & $\begin{array}{l}\text { ovaries of sheep under } \\
\text { different nutritional status }\end{array}$ & small RNA seq & [103] \\
\hline & human & adult ovary & small RNA seq & [104] \\
\hline & mouse & $\begin{array}{l}\text { ovaries of mice with/without } \\
\text { cigarette smoke exposure }\end{array}$ & microarray & {$[105]$} \\
\hline \multirow[t]{4}{*}{ Follicle } & bovine & during follicular development & microarray & [43] \\
\hline & goat & multi/uniparous goat ovary & miRNA seq & {$[106]$} \\
\hline & sheep & $\begin{array}{l}\text { growing/preovulatory follicles/ } \\
\text { corpora lutea }\end{array}$ & miRNA seq & {$[45]$} \\
\hline & porcine & $\begin{array}{l}\text { healthy/early atretic/progressed } \\
\text { atretic follicles }\end{array}$ & microarray & [42] \\
\hline $\operatorname{COC}$ & bovine & COCs during late oogenesis & miRNA seq & {$[107]$} \\
\hline Oocyte & human & oocytes during meiosis & microarray & [108] \\
\hline \multirow[t]{6}{*}{ GCs } & human & $\begin{array}{l}\text { cumulus GCs from women with } \\
\text { and without PCOS }\end{array}$ & miRNA seq & [109] \\
\hline & human & $\begin{array}{l}\text { GCs from exogenous gonadotropins } \\
\text { hyperresponders/normal responders }\end{array}$ & microarray & [110] \\
\hline & human & $\begin{array}{l}\text { GCs and serum from normal cycling } \\
\text { and DOR women }\end{array}$ & microarray & [111] \\
\hline & mouse & $\begin{array}{l}\text { GCs from mice before and after an } \\
\text { ovulatory dose of hCG treatment }\end{array}$ & microarray & [112] \\
\hline & bovine & GCs of subordinate/dominant follicles & miRNA seq & [48] \\
\hline & bovine & GCs of large/small follicles & microarray & {$[47]$} \\
\hline \multirow[t]{3}{*}{ Follicular fluid } & human & PCOS patients and healthy controls & $\begin{array}{l}\text { small RNA seq } \\
\& P C R \text { array }\end{array}$ & [113] \\
\hline & human & PCOS patients and healthy controls & PCR array & [114] \\
\hline & human & follicular fluid compares with plasma & PCR array & [115] \\
\hline \multirow[t]{2}{*}{ EV } & bovine & EV from small/medium/large follicles & small RNA seq & [44] \\
\hline & bovine & EV from GCs, COCs and their EVs & PCR array & [116] \\
\hline \multirow[t]{2}{*}{ Serum } & human & $\begin{array}{l}\text { serum from PCOS patients with } \\
\text { IGM/NGT and healthy controls }\end{array}$ & PCR array & {$[117]$} \\
\hline & human & serum from POF/normal women & microarray & [60] \\
\hline
\end{tabular}

Note: COC represents cumulus-oocyte complexes, EV represents extracellular vesicles

in recent years. It is known that miR-224 and miR-26b regulate the pathway by targeting SMAD4 [63, 64]; miR-23a and miR-27a promote human GC apoptosis by targeting SMAD5, as described above, while miR-92a, miR-181b and miR-182 directly bind to SMAD7 [65-
67], which is considered an antagonist of the TGF $\beta$ pathway [68] and an amplifier of TGF $\beta$-induced apoptosis [69]. Interestingly, miR-92a belongs to the miR-17-92 cluster, which includes miR-17, miR-18a, miR-19a, miR-19b, miR-20a, and miR-92a and is activated via 


\section{Atresia}

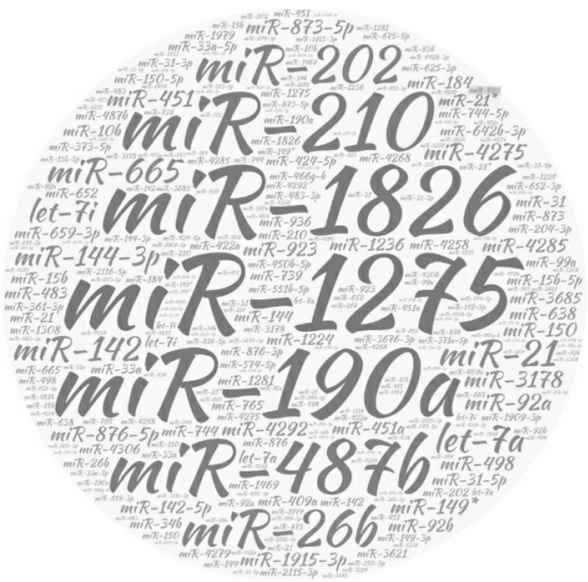

Development

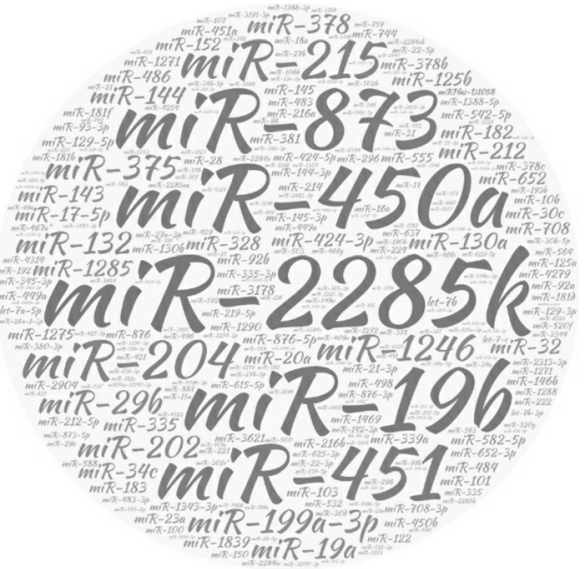

Fig. 1 A glance at the main miRNAs that play roles in atresia and follicular development processes. Note: a larger font size represents a higher frequency of a certain miRNA that was reported in related studies

directly binding the $M Y C N / M Y C$ promoter. Although other members of the cluster have rarely been reported in the ovary, the cluster has been shown to regulate the TGF $\beta$ pathway and affect apoptosis in many biological processes, including tumourigenesis and normal development of the heart, lungs, and immune system [70]. Studies on cancer cell lines suggest that the cluster acts as a potent inhibitor of the TGF $\beta$ pathway [71] by directly binding to multiple pathway components, especially SMADs in neuroblastoma [72]. The cluster may also mediate the antiproliferative effect of histone deacetylase inhibitors via the proapoptotic protein BIM (Bcl-2-interacting mediator of cell death) [73]. Further, studies on miRNA-mediated TGF $\beta / S M A D$ signalling may provide a comprehensive understanding of the TGF $\beta /$ SMAD signalling regulation and functions in GC apoptosis and follicular atresia.

\section{miR-23-27-24 cluster, miR-183-96-182 cluster and other potential miRNA clusters}

Close evolutionary, transcriptional and functional relationships among related homologous/clustered miRNAs have been revealed by bioinformatics analyses [74]. The miR-23-27-24 cluster comprises the miR-23a gene cluster (including the miR-23a, miR-27a and miR-24-2 genes) and the miR-23b cluster (including the mir-23b, mir-27b and mir-24-1 genes), which are located on chromosomes 19(-) and 9(+), respectively, in the human genome. Studies have suggested that the miR-23-27-24 cluster plays roles in various biological and pathological processes, including erythropoiesis [75], angiogenesis [76], cell invasion and hepatic metastasis [77]. In human ovarian follicles, upregulation of mir-23a and mir-27a was observed in POF patients [60]. A functional study showed that SMAD5 is a direct target of both mir-23a and mir-27a, which promote GC apoptosis via the Fas-FasL pathway [78]. These observations suggest that miRNA clusters play a role in follicular atresia. Clearly, the functions of other members of the miR-23-27-24 cluster and whether they share coordinate function in the process of follicular atresia deserve further research.

The miR-183-96-182 cluster is highly conserved, and its members are located within a $5 \mathrm{~kb}$ region on human chromosome 7q32.2 [79]. Expression of the miR-18396-182 cluster has been reported in both follicular and luteal cells. The expression levels of members of this cluster are higher in preovulatory dominant follicles than in subordinate follicles [48] and further increased in luteal tissues [80]. Members of the miR-183-96-182 cluster were validated to target the 3'-UTR of the FOXO1 gene, an important transcription factor for follicle-stimulating hormone responsive genes in ovarian GC [81, 82], and thus regulate follicular and luteal development via exerting effects on cell survival and steroid production. miR-182 was also reported to inhibit GC apoptosis by targeting SMAD7 [66]. It has been reported that the miR-183-96-182 cluster is regulated by the $\mathrm{Wnt} / \mathrm{\beta}-\mathrm{Ca}$ tenin pathway via direct interaction between CTNNB1 and the promoter region of its coding gene. In addition, the miR-99b/let-7e/miR-125a cluster, which works co-ordinately to regulate ARID3A (AT-rich interaction domain 3A) in oesophageal squamous cell carcinoma [83], and the miR-106a-363 cluster (miR-20b, miR-106a, miR-363-3p, and miR-363-5p), which inhibits the proliferation of oral squamous carcinoma cells by decreasing the expression of several sibling miRNAs encoded by the miR-17-92 or miR-106b-25 cluster [84], may also play roles in follicular atresia, as other members of the let7 
Table 2 miRNAs, target genes and their functions in GC apoptosis and follicular atresia

\begin{tabular}{|c|c|c|c|c|}
\hline miRNA & Species & Target & Function & Reference \\
\hline let-7g & porcine & MAP3K1 & promotes GC apoptosis & [61] \\
\hline let-7 g & porcine & TGFBR1 & promotes GC apoptosis & [58] \\
\hline miR-10b & goat & $B D N F$ & suppresses GC proliferation & [118] \\
\hline miR-15a & human & unknown & $\begin{array}{l}\text { promotes release of } \\
\text { progesterone and } \\
\text { testosterone }\end{array}$ & [91] \\
\hline miR-21 & mouse & unknown & $\begin{array}{l}\text { inhibits apoptosis, increases } \\
\text { ovulation rate }\end{array}$ & [119] \\
\hline miR-22 & mouse & Sirt1 & inhibits GC apoptosis & [120] \\
\hline miR-23a & human & SMAD5 & promotes GC apoptosis & {$[78,121]$} \\
\hline miR-26b & porcine & ATM & promotes GC apoptosis & [42] \\
\hline miR-26b & porcine & SMAD4 & promotes GC apoptosis & [64] \\
\hline miR-26b & porcine & HAS2 & promotes GC apoptosis & [122] \\
\hline miR-27a & human & SMAD5 & promotes GC apoptosis & [78] \\
\hline miR-34a & porcine & INHBB & promotes GC apoptosis & [123] \\
\hline miR-34c & porcine & unknown & $\begin{array}{l}\text { proapoptotic and } \\
\text { antiproliferative factor }\end{array}$ & [124] \\
\hline miR-92a & porcine & SMAD7 & inhibits GC apoptosis & [65] \\
\hline miR-93 & human & CDKN1A & promotes GC proliferation & [125] \\
\hline miR-106a & human & $\begin{array}{l}\text { apoptosis signal-regulating } \\
\text { kinase } 1 \text { (ASK1) }\end{array}$ & $\begin{array}{l}\text { reduces GC viability and } \\
\text { promotes apoptosis }\end{array}$ & [111] \\
\hline miR-125a-5p & mouse & Stat3 & promotes GC apoptosis & [126] \\
\hline $\operatorname{miR}-126^{*}$ & porcine & FSHR & $\begin{array}{l}\text { promotes AR-induced } \\
\text { GC apoptosis }\end{array}$ & [127] \\
\hline miR-146a & human & IRAK1/TRAF6 & promotes GC apoptosis & [128] \\
\hline miR-181b & porcine & SMAD7 & inhibits GC apoptosis & [67] \\
\hline miR-182 & rat & Smad7 & inhibits GC apoptosis & [66] \\
\hline miR-224 & mouse & Smad4 & $\begin{array}{l}\text { inhibits GC proliferation } \\
\text { and E2 release }\end{array}$ & [63] \\
\hline miR-320 & mouse & $E 2 f 1 / S f-1$ & $\begin{array}{l}\text { inhibits E2 synthesis and } \\
\text { GC proliferation }\end{array}$ & [129] \\
\hline miR-378-3p & bovine & $P G R$ & inhibits GC differentiation & [130] \\
\hline miR-378 & porcine & CYP19A1 & decreases E2 production & [88] \\
\hline miR-383 & mouse & Rbms 1 & enhances E2 release from GCs & [131] \\
\hline miR-503/322/351 Cluster & mouse & $\begin{array}{l}\text { Autophagy/Mitophagy- } \\
\text { Associated Genes }\end{array}$ & $\begin{array}{l}\text { reduces of mitochondrial } \\
\text { activity in GC }\end{array}$ & [132] \\
\hline miR-764-3p & mouse & $S f-1$ & decreases steroidogenesis & [89] \\
\hline miR-1275 & porcine & $\mathrm{LRH}-1$ & represses E2 synthesis & [50] \\
\hline
\end{tabular}

family and miR-106a alone have been shown to function in the atresia process.

\section{miRNAs and steroidogenesis}

Gonadal hormones, such as oestrogen and progesterone, play significant roles in both the endocrine and intracrine regulation of all aspects of female reproduction. In ovaries, the miRNA regulation of steroidogenesis and hormone secretion has a direct impact on the follicular atresia process. The steroidogenic acute regulatory
(STAR) protein facilitates cholesterol transport to supply substrates for steroid hormone biosynthesis. Although let-7 [85] and miR-150 [86] were reported to directly inhibit Star at the post-transcriptional level in Leydig cells, the only miRNA known to regulate Star in ovary is miR-133b, which directly targeting Foxl2 thus inhibits the Foxl2-mediated transcriptional repression of Star and Cyp19a1 to promote oestradiol production [87]. When it comes to the main aromatase CYP19A1, miR-378 reduces oestrogen synthesis by directly binding 
to CYP19A1 [88]. Other miRNAs that indirectly regulate CYP19A1 include miR-320 and miR-383, which directly target E2F1/SF1 and eventually affect the expression of their downstream gene CYP19A1; miR764-3p, which directly binds to SF1 [89]; and miR-1275, which targets another CYP19A1 transcription factor, LRH1 [50]. In a spermatogenesis study, the long noncoding RNA NLC1-C was reportedly associated with testicular embryonal carcinoma cell proliferation by functioning as a miR-320a/383-sponge that repressed miR-320a and miR-383 transcripts [90]. This mechanism may be worthy of further exploration in the ovary. However, the miRNAs involved in progesterone synthesis have not been studied as extensively. miR-15a was reported to promote the release of progesterone and testosterone, but the target gene and regulatory mechanism are unclear [91]. The relationship between alterations in steroidogenesis and GC apoptosis has been demonstrated in several studies [92]. Our transcriptomic study on healthy and early atretic follicles also suggested a major role of steroidogenesis in atresia initiation [93]. Therefore, a deeper understanding of miRNA-mediated steroidogenesis regulation will be a promising area in follicular development and atresia research.

\section{Bioinformatic predictions of key miRNA-mediated pathways in the atresia process}

To further explore possible miRNA-mediated pathways involved in follicular atresia, we applied bioinformatics integration and mining of existing functional miRNAs. All known atresia-related miRNAs (from Table 2) were used as starting points. Their target genes, which were experimentally confirmed by a luciferase reporter assay, were screened using miRTarBase (http://mirtarbase.mbc.nctu.edu.tw/ php/search.php) [94], and 426 genes were obtained (Additional file 1: Table S1). Then, we performed functional enrichment analyses of target genes using the Cytoscape plug-in ClueGO and the latest KEGG, REACTOME and WikiPathways databases (Additional file 2: Table S2, Additional file 3: Table S3, Additional file 4: Table S4). The functional enrichment generated from KEGG showed that most highlighted pathways were related to cancers of various types, largely because miRNA studies have mostly focused on cancer models. Nonetheless, excluding cancer-related pathways, signalling pathways that include TGF- $\beta$, PI3K-Akt, p53, FoxO, TNF, Toll-like receptor, HIF-1, WNT VEGF, oestrogen, progesterone and insulin mediation appear to play roles in the processes of follicular atresia and GC apoptosis. These results mostly coincide with known signalling pathways that function in ovarian development, maturation and atresia. Detailed information can be found in the supplementary tables.

\section{Conclusions}

miRNA-mediated regulation is now widely valued in ovarian function studies. Although the mechanisms of follicular atresia have not been precisely defined, recent reports have demonstrated a causal link between the levels of certain miRNAs and the fate of GCs/follicles in several species. Profiling studies have demonstrated that diversified miRNAs play roles in various ovarian physiological and pathological processes. In the specific area of follicular atresia and GC apoptosis, some miRNAs are known to work individually to regulate particular genes, while others function in clusters to finely adjust certain signalling pathways or cellular processes. However, in both cases, the function of miRNAs should not be viewed as a single factor but as part of a regulatory network that involves hormones, growth factors and other regulatory noncoding RNAs from each component of the follicle. The ultimate functions of miRNAs on certain target genes can be affected by multilevel regulatory networks, from the transcriptional regulation of their own coding genes to interference from other competing endogenous RNAs, to achieve timely adjustment in cells. Therefore, the following areas may attract more attention in future studies: 1 ) competition and cooperation of regulatory noncoding RNAs, such as miRNAs, lncRNAs (long noncoding RNAs) and piRNAs (Piwi-interacting RNAs); 2) communication among miRNAs generated from different parts of the follicle, including oocytes, GCs (from the cumulus or near basement membrane) and thecal cells; 3) influence of single-nucleotide polymorphisms (SNPs) on miRNA genes that are involved in ovarian pathological processes; and 4) functions of small RNAs in EV. In addition, with the development of high-throughput methods, comprehensive studies on noncoding RNA networks and interactions with their targets will lead to a deeper understanding of miRNA functions in ovarian follicular atresia. The advancement of our knowledge of miRNA-mediated networks will not only help elucidate the mechanisms of GC apoptosis, follicular development, atresia and other disorders but also provide potential uses for future clinical diagnosis and treatment.

\section{Additional files}

Additional file 1: Table S1. (XLSX $13.9 \mathrm{~kb}$ )

Additional file 2: Table S2. (XLS $85 \mathrm{~kb}$ ) 
Additional file 3: Table S3. (XLS $198 \mathrm{~kb})$

Additional file 4: Table S4. (XLS $82 \mathrm{~kb}$ )

\section{Abbreviations}

COC: Cumulus-oocyte complexes; EV: Extracellular vesicles; GC: Granulosa cell; IncRNAs: Long noncoding RNAs; miRNAs: MicroRNAs; PCOS: Polycystic ovary syndrome; piRNAs: Piwi-interacting RNAs; POF: Premature ovarian failure

\section{Acknowledgements}

We are grateful to all the participants involved in this study.

\section{Funding}

This work was supported by the National Natural Science Foundation of China (grant no. 31672421), the Natural Science Foundation of Jiangsu Province (grant nos. BK20161453 and BK20160721) and the Fundamental Research Funds for the Central Universities (grant no. KYZ201644).

\section{Availability of data and materials}

The datasets used and/or analysed during the current study are available from the corresponding author upon reasonable request.

\section{Authors' contributions}

$\mathrm{JZ}, \mathrm{ZP}, \mathrm{YX}$ and $\mathrm{HL}$ contributed to the initiation and discussion of the manuscript. $J Z$ and ZP contributed equally to the manuscript preparation. All authors read and approved the final manuscript.

\section{Ethics approval and consent to participate}

Not applicable.

\section{Consent for publication}

Not applicable.

\section{Competing interests}

The authors declare that they have no competing interests.

\section{Publisher's Note}

Springer Nature remains neutral with regard to jurisdictional claims in published maps and institutional affiliations.

Received: 17 September 2018 Accepted: 17 December 2018 Published online: 10 January 2019

\section{References}

1. Quirk SM, Cowan RG, Harman RM, Hu CL, Porter DA. Ovarian follicular growth and atresia: the relationship between cell proliferation and survival. J Anim Sci. 2004;82(E-Suppl):E40-52

2. Baker TG. A quantitative and cytological study of germ cells in human ovaries. Proc R Soc Lond B Biol Sci. 1963;158:417-33.

3. Brachova P, Hung WT, Mcginnis LK, Christenson LK. MicroRNA regulation of endocrine functions in the ovary. In: Menon, Goldstrohm, editors. Posttranscriptional Mechanisms in Endocrine Regulation. Cham: Springer; 2016.

4. Faddy M, Gosden R, Gougeon A, Richardson SJ, Nelson J. Accelerated disappearance of ovarian follicles in mid-life: implications for forecasting menopause. Hum Reprod. 1992;7:1342-6.

5. Manabe N, Goto Y, Matsudaminehata F, Inoue N, Maeda A, Sakamaki K, Miyano T. Regulation mechanism of selective atresia in porcine follicles: regulation of granulosa cell apoptosis during atresia. J Reprod Dev. 2004;50:493-514.

6. Moor R, HAY MF, Dott H, Cran D. Macroscopic identification and steroidogenic function of atretic follicles in sheep. J Endocrinol. 1978; 77:309-18.

7. Maeda A, Goto Y, Matsuda-Minehata F, Cheng Y, Inoue N, Manabe N. Changes in expression of interleukin-6 receptors in granulosa cells during follicular atresia in pig ovaries. J Reprod Dev. 2007;53:727-36.

8. Rodgers RJ, Irving-Rodgers HF. Morphological classification of bovine ovarian follicles. Reproduction. 2010;139:309-18.

9. Nishimoto $\mathrm{H}$, Hamano $\mathrm{S}$, Hill GA, Miyamoto A, Tetsuka M. Classification of bovine follicles based on the concentrations of steroids, glucose and lactate in follicular fluid and the status of accompanying follicles. J Reprod Dev. 2009;55:219.

10. Rosales-Torres AM, Avalos-Rodriguez A, Vergara-Onofre M, HernandezPerez O, Ballesteros LM, Garcia-Macedo R, Ortiz-Navarrete $V$, Rosado A Multiparametric study of atresia in ewe antral follicles: histology, flow cytometry, internucleosomal DNA fragmentation, and lysosomal enzyme activities in granulosa cells and follicular fluid. Mol Reprod Dev. 2000;55:270-81.

11. Jinbi Z, Fei L, Zengxiang $P$, et al. Comparative study of methods to determine the follicular atresia extent in pigs. J Nanjing Agric Univ. 2013;1: $115-9$

12. Marion GB, Gier HT, Choudary JB. Micromorphology of the bovine ovarian follicular system. J Anim Sci. 1968:27:451.

13. Tilly $\mathrm{J}$, Kowalski KI, Johnson AL, Hsueh AJ. Involvement of apoptosis in ovarian follicular atresia and postovulatory regression. Endocrinology. 1991;129:2799-801.

14. Hughes FM Jr, Gorospe WC. Biochemical identification of apoptosis (programmed cell death) in granulosa cells: evidence for a potential mechanism underlying follicular atresia. Endocrinology. 1991;129:2415-22.

15. Jolly PD, Tisdall DJ, Heath DA, Lun S, McNatty KP. Apoptosis in bovine granulosa cells in relation to steroid synthesis, cyclic adenosine 3',5'monophosphate response to follicle-stimulating hormone and luteinizing hormone, and follicular atresia. Biol Reprod. 1994;51:934-44.

16. Murdoch WJ. Programmed cell death in preovulatory ovine follicles. Biol Reprod. 1995;53:8-12.

17. Sugimoto M, Manabe N, Kimura Y, MYOUMOTO A, IMAI Y, OHNO H MIYAMOTO H. Ultrastructural changes in granulosa cells in porcine antral follicles undergoing atresia indicate apoptotic cell death. J Reprod Dev. 1998:44:7-14.

18. Matsuda-Minehata F, Inoue N, Goto $Y$, Manabe N. The regulation of ovarian granulosa cell death by pro-and anti-apoptotic molecules. J Reprod Dev. 2006:52:695-705.

19. Manabe N, Kimura Y, Uchio K, Tajima C, Matsushita H, Nakayama M, Sugimoto M, Miyamoto $\mathrm{H}$. Regulatory mechanisms of granulosa cell apoptosis in ovarian follicle atresia. In: Ikura K, Nagao M, Masuda S, Sasaki R, editors. Animal cell technology: challenges for the 21st century. Dordrecht: Springer; 2002. p. 343-7.

20. Yu YS, Sui HS, Han ZB, Li W, Luo MJ, Tan JH. Apoptosis in granulosa cells during follicular atresia: relationship with steroids and insulin-like growth factors. Cell Res. 2004;14:341-6.

21. Hussein MR. Apoptosis in the ovary: molecular mechanisms. Hum Reprod Update. 2005;11:162-78.

22. Jääskeläinen $M$, Kyrönlahti $A$, Anttonen $M$, Nishi $Y$, Yanase $T$, Secchiero $P$, Zauli G, Tapanainen J, Heikinheimo M, Vaskivuo T. TRAIL pathway components and their putative role in granulosa cell apoptosis in the human ovary. Differentiation. 2009;77:369-76.

23. Dressing GE, Pang $Y$, Dong J, Thomas P. Progestin signaling through $\mathrm{mPRa}$ in Atlantic croaker granulosa/theca cell cocultures and its involvement in progestin inhibition of apoptosis. Endocrinology. 2010; 151:5916-26.

24. Saller S, Kunz L, Dissen G, Stouffer R, Ojeda S, Berg D, Berg U, Mayerhofer A. Oxytocin receptors in the primate ovary: molecular identity and link to apoptosis in human granulosa cells. Hum Reprod. 2010. https://doi.org/10. 1093/humrep/dep467

25. Lee $Y$, Kim M, Han J, Yeom KH, Lee S, Baek SH, Kim VN. MicroRNA genes are transcribed by RNA polymerase II. EMBO J. 2004;23:4051-60.

26. Tanzer A, Stadler PF. Molecular evolution of a microRNA cluster. J Mol Biol. 2004:339:327-35.

27. Chang T-C, Pertea M, Lee S, Salzberg SL, Mendell JT. Genome-wide annotation of microRNA primary transcript structures reveals novel regulatory mechanisms. Genome Res. 2015;25:1401-9.

28. Kwon SC, Nguyen TA, Choi Y-G, Jo MH, Hohng S, Kim VN, Woo J-S. Structure of human DROSHA. Cell. 2016;164:81-90.

29. Meister G, Landthaler M, Patkaniowska A, Dorsett Y, Teng G, Tuschl T. Human Argonaute2 mediates RNA cleavage targeted by miRNAs and siRNAs. Mol Cell. 2004;15:185-97.

30. Wahid F, Shehzad A, Khan T, Kim YY. MicroRNAs: synthesis, mechanism, function, and recent clinical trials. Biochim Biophys Acta. 1803;2010:1231-43

31. Friedman RC, Farh KK-H, Burge CB, Bartel DP. Most mammalian mRNAs are conserved targets of microRNAs. Genome Res. 2009;19:92-105. 
32. Donadeu FX, Schauer SN, Sontakke SD. Involvement of miRNAs in ovarian follicular and luteal development. J Endocrinol. 2012;215:323-34.

33. Hossain MM, Sohel MM, Schellander K, Tesfaye D. Characterization and importance of microRNAs in mammalian gonadal functions. Cell Tissue Res. 2012;349:679-90

34. Imbar T, Eisenberg I. Regulatory role of microRNAs in ovarian function. Fertil Steril. 2014;101:1524-30.

35. Christenson LK. MicroRNA control of ovarian function. Anim Reprod. 2010;7:129-33.

36. Maalouf SW, Liu WS, Pate JL. MicroRNA in ovarian function. Cell Tissue Res 2016;363:7-18

37. Mcginnis LK, Luense L, Christenson LK. MicroRNA in ovarian biology and disease. Cold Spring Harb Perspect Med. 2015;5(9):a022962.

38. Li Y, Fang Y, Liu Y, Yang X. MicroRNAs in ovarian function and disorders. J Ovarian Res. 2015;8:1-8.

39. Hao W, Guo Y, Hao GM, Wang W. Research progress on miRNArelated mechanism of polycystic ovary syndrome. J Reprod Med. 2016;12:1126-9

40. Wu N, Gaur U, Zhu Q, Chen B, Xu Z, Zhao X, Yang M, Li D. Expressed microRNA associated with high rate of egg production in chicken ovarian follicles. Anim Genet. 2017:48:205-16.

41. Jing $Y$, Ke H, Ren T, Lou Y, Zhao A. High-throughput sequencing reveals differential expression of miRNAs in prehierarchal follicles of laying and brooding geese. Physiol Genomics. 2016;48:455-63.

42. Lin F, Li R, Pan ZX, Zhou B, Yu DB, Wang XG, Ma XS, Han J, Shen M, Liu HL. miR-26b promotes granulosa cell apoptosis by targeting ATM during follicular atresia in porcine ovary. PLoS One. 2012;7:e38640.

43. Sontakke SD, Mohammed BT, McNeilly AS, Donadeu FX. Characterization of microRNAs differentially expressed during bovine follicle development. Reproduction. 2014;148:271-83.

44. Raphatphorn N, Wei-Ting H, Sumedha G, Davis JS, Wilaiwan C, Christenson LK. Characterization and small RNA content of extracellular vesicles in follicular fluid of developing bovine antral follicles. Sci Rep. 2016;6:25486.

45. McBride D, Carré W, Sontakke SD, Hogg CO, Law A, Donadeu FX, Clinton M. Identification of miRNAs associated with the follicular-luteal transition in the ruminant ovary. Reproduction. 2012;144:221-33.

46. Yang S, Wang S, Luo A, Ding T, Lai Z, Shen W, Ma X, Cao C, Shi L, Jiang J, et al. Expression patterns and regulatory functions of microRNAs during the initiation of primordial follicle development in the neonatal mouse ovary. Biol Reprod. 2013;89:126.

47. Bahrami A, Miraieashtiani SR, Sadeghi M, Najafi A. miRNA-mRNA network involved in folliculogenesis interactome: systems biology approach. Reproduction. 2017;154. https://doi.org/10.1530/REP-17-0049.

48. Gebremedhn S, Salilew-Wondim D, Ahmad I, Sahadevan S, Hossain MM, Hoelker M, Rings F, Neuhoff C, Tholen E, Looft C, et al. MicroRNA expression profile in bovine granulosa cells of Preovulatory dominant and subordinate follicles during the late follicular phase of the estrous cycle. PLoS One. 2015; 10:e0125912.

49. Fawzy IO, Hamza MT, Hosny KA, Esmat G, El Tayebi HM, Abdelaziz Al. miR-1275: a single microRNA that targets the three IGF2-mRNA-binding proteins hindering tumor growth in hepatocellular carcinoma. FEBS Lett. 2016;589:2257-65.

50. Liu J, Li X, Yao Y, Li Q, Pan Z, Li Q. miR-1275 controls granulosa cell apoptosis and estradiol synthesis by impairing LRH-1/CYP19A1 axis. Biochim Biophys Acta. 2018;1861:246.

51. Hirata H, Hinoda Y, Ueno K, Shahryari V, Tabatabai ZL, Dahiya R. MicroRNA1826 targets VEGFC, beta-catenin (CTNNB1) and MEK1 (MAP2K1) in human bladder cancer. Carcinogenesis. 2012;33:41-8.

52. Hao Y, Yang J, Yin S, Zhang H, Fan Y, Sun C, Gu J, Xi JJ. The synergistic regulation of VEGF-mediated angiogenesis through miR-190 and target genes. RNA. 2014;20:1328-36.

53. Chu HW, Cheng CW, Chou WC, Hu LY, Wang HW, Hsiung CN, Hsu HM, Wu PE, Hou MF, Shen CY. A novel estrogen receptor-microRNA 190a-PAR-1pathway regulates breast cancer progression, a finding initially suggested by genome-wide analysis of loci associated with lymph-node metastasis. Hum Mol Genet. 2014;23:355-67.

54. Giannakakis A, Sandaltzopoulos R, Greshock J, Liang S, Huang J, Hasegawa K, Li C, O'Brienjenkins A, Katsaros D, Weber BL. miR-210 links hypoxia with cell cycle regulation and is deleted in human epithelial ovarian cancer. Cancer Biol Ther. 2008;7:255-64.
55. Gee HE, Camps C, Buffa FM, Patiar S, Winter SC, Betts G, Homer J, Corbridge $R$, Cox G, West CM. hsa-mir-210 is a marker of tumor hypoxia and a prognostic factor in head and neck cancer. Cancer. 2010;116:2148-58.

56. Su JL, Chen PS, Johansson G, Kuo ML. Function and regulation of let-7 family microRNAs. MicroRNA. 2012;1(1):34-9.

57. Roush S, Slack FJ. The let-7 family of microRNAs. Trends Cell Biol. 2008; 18:505-16.

58. Zhou J, Liu J, Pan Z, Du X, Li X, Ma B, Yao W, Li Q, Liu H. The let-7g microRNA promotes follicular granulosa cell apoptosis by targeting transforming growth factor- $\beta$ type 1 receptor. Mol Cell Endocrinol. 2015;409:103-12.

59. Cao R, Wu WJ, Zhou XL, Xiao P, Wang Y, Liu HL. Expression and preliminary functional profiling of the let-7 family during porcine ovary follicle atresia. Mol Cells. 2015:38:304-11.

60. Zhou Y, Zhu YZ, Zhang SH, Wang HM, Wang SY. MicroRNA expression profiles in premature ovarian failure patients and its potential regulate functions. Chin J Birth Health Hered. 2011;5:20-2.

61. Cao R, Wu W, Zhou X, Liu K, Li B, Huang X, Zhang Y, Liu H. Let-7g induces granulosa cell apoptosis by targeting MAP3K1 in the porcine ovary. Int J Biochem Cell Biol. 2015;68:148-57.

62. Heldin CH, Landström M, Moustakas A. Mechanism of TGF- $\beta$ signaling to growth arrest, apoptosis, and epithelial-mesenchymal transition. Curr Opin Cell Biol. 2009;21:166.

63. Yao G, Yin M, Lian J, Tian H, Liu L, Li X, Sun F. MicroRNA-224 is involved in transforming growth factor-beta-mediated mouse granulosa cell proliferation and granulosa cell function by targeting Smad4. Mol Endocrinol. 2010;24:540-51.

64. Liu J, Du X, Zhou J, Pan Z, Liu H, Li Q. MicroRNA-26b functions as a proapoptotic factor in porcine follicular granulosa cells by targeting Sma-and mad-related protein 4. Biol Reprod. 2014;91:146.

65. Liu J, Yao W, Yao Y, Du X, Zhou J, Ma B, Liu H, Li Q, Pan Z. MiR-92a inhibits porcine ovarian granulosa cell apoptosis by targeting Smad7 gene. FEBS Lett. 2014:588:4497-503.

66. Lu J, Zhang C, Gu B, Zhang S, Geng J, Chen Y, Xie J. MicroRNA-182 inhibits rat ovarian granulosa cell apoptosis by targeting Smad7 in polycystic ovarian syndrome. Int J Clin Exp Pathol. 2017;10:1380-7.

67. Yao W, Pan Z, Du X, Zhang J, Li Q. miR-181 b-induced SMAD7 downregulation controls granulosa cell apoptosis through TGF-Î2 signaling by interacting with the TGFBR1 promoter. J Cell Physiol. 2018;233(9):6807-21.

68. Nakao A, Afrakhte M, Morn A, Nakayama T, Christian JL, Heuchel R, Itoh S, Kawabata M, Heldin NE, Heldin, Amp CH. Identification of SMAD7, a TGFßinducible antagonist of TGF- $\beta$ signalling. Nature. 1997;389:631-5.

69. Schiffer M, Bitzer M, Roberts IS, Kopp JB, Ten DP, Mundel P, Böttinger EP Apoptosis in podocytes induced by TGF-beta and Smad7. J Clin Invest. 2001;108:807-16.

70. Mendell JT. miRiad roles for the miR-17-92 cluster in development and disease. Cell. 2008;133:217-22.

71. Dews M, Fox JL, Hultine S, Sundaram P, Wang W, Liu YY, Furth E, Enders GH, El-Deiry W, Schelter JM. The myc-miR-17 92 axis blunts TGF-beta signaling and production of multiple TGF\{beta\}-dependent antiangiogenic factors. Cancer Res. 2010;70:8233-46

72. Mestdagh $P$, Boström AK, Impens F, Fredlund E, Van PG, De AP, Von SK Ghesquière $B$, Schulte $S$, Dews M. The miR-17-92 microRNA cluster regulates multiple components of the TGF- $\beta$ pathway in neuroblastoma. Mol Cell. 2010;40:762-73.

73. Talbert DR, Wappel RL, Moran DM, Shell SA, Bacus SS. The role of Myc and the miR-17 92 cluster in histone deacetylase inhibitor induced apoptosis of solid tumors. J Cancer Ther. 2013;04:907-18.

74. Liang T, Yu J, Liu C, Guo L. An exploration of evolution, maturation, expression and function relationships in mir-23 $\sim 27 \sim 24$ cluster. PLoS One. 2014;9:e106223.

75. Wang F, Zhu Y, Guo L, Dong L, Liu H, Yin H, Zhang Z, Li Y, Liu C, Ma Y, et al. A regulatory circuit comprising GATA1/2 switch and microRNA-27a/24 promotes erythropoiesis. Nucleic Acids Res. 2014;42:442-57.

76. Zhou Q, Gallagher R, Ufret-Vincenty R, Li X, Olson EN, Wang S. Regulation of angiogenesis and choroidal neovascularization by members of microRNA23 27 24 clusters. Proc Natl Acad Sci U S A. 2011;108:8287-92.

77. Li X, Liu X, Xu W, Zhou P, Gao P, Jiang S, Lobie PE, Zhu T. c-MYC-regulated miR-23a/24-2/27a cluster promotes mammary carcinoma cell invasion and hepatic metastasis by targeting Sprouty2. J Biol Chem. 2013;288:18121-33.

78. Nie M, Yu S, Peng S, Fang Y, Wang H, Yang X. miR-23a and miR-27a promote human granulosa cell apoptosis by targeting SMAD5. Biol Reprod. 2015;93:98. 
79. Li P, Sheng C, Huang L, Zhang H, Huang L, Cheng Z, Zhu Q. MiR-183/-96/ -182 cluster is up-regulated in most breast cancers and increases cell proliferation and migration. Breast Cancer Res. 2014;16:473.

80. Mohammed BT, Sontakke SD, loannidis J, Duncan WC, Donadeu FX. The adequate corpus luteum: miR-96 promotes luteal cell survival and progesterone production. J Clin Endocrinol Metab. 2017;102:2188.

81. Shi F, Lapolt PS. Relationship between FoxO1 protein levels and follicular development, atresia, and luteinization in the rat ovary. J Endocrinol. 2003; 179:195-203.

82. Herndon MK, Law NC, Donaubauer EM, Kyriss B, Hunzicker-Dunn M. Forkhead box $\mathrm{O}$ member FOXO1 regulates the majority of folliclestimulating hormone responsive genes in ovarian granulosa cells. Mol Cell Endocrinol. 2016;434:116-26.

83. Ma J, Zhan Y, Xu Z, Li Y, Luo A, Ding F, Cao X, Chen H, Liu Z. ZEB1 induced miR-99b/let-7e/miR-125a cluster promotes invasion and metastasis in esophageal squamous cell carcinoma. Cancer Lett. 2017;398:37-45.

84. Khuu C, Jevnaker AM, Bryne M, Osmundsen $\mathrm{H}$. An investigation into antiproliferative effects of microRNAs encoded by the miR-106a-363 cluster on human carcinoma cells and keratinocytes using microarray profiling of miRNA transcriptomes. Front Genet. 2014;5:246.

85. Men $Y$, Fan $Y$, Shen $Y$, Lu L, Kallen AN. The steroidogenic acute regulatory protein (StAR) is regulated by the H19/let-7 Axis. Endocrinology. 2017;158:402-9.

86. Geng XJ, Zhao DM, Mao GH, Tan L. MicroRNA-150 regulates steroidogenesis of mouse testicular Leydig cells by targeting STAR. Reproduction. 2017;154:129.

87. Dai A, Sun H, Fang T, Zhang Q, Wu S, Jiang Y, Ding L, Yan G, Hu Y. MicroRNA-133b stimulates ovarian estradiol synthesis by targeting Foxl2. FEBS Lett. 2013;587:2474-82.

88. Xu S, Linhermelville K, Yang BB, Wu D, Li J. Micro-RNA378 (miR-378) regulates ovarian estradiol production by targeting aromatase. Endocrinology. 2011;152:3941-51.

89. Wang L, Cong L, Rong L, Deng Y, Tan Y, Chao T, Qi H. MicroRNA-764$3 p$ regulates $17 \beta$-estradiol synthesis of mouse ovarian granulosa cells by targeting steroidogenic factor-1. In Vitro Cell Dev Biol Anim. 2016;52: 365-73.

90. Lü $M$, Tian $H$, Cao $Y$, He $X$, Chen L, Song $X$, Ping $P$, Huang $H$, Sun F. Downregulation of miR-320a/383-sponge-like long non-coding RNA NLC1-C (narcolepsy candidate-region 1 genes) is associated with male infertility and promotes testicular embryonal carcinoma cell proliferation. Cell Death Dis. 2015;6:e1960.

91. Sirotkin AV, Kisová G, Brenaut P, Ovcharenko D, Grossmann R, Mlyncek M. Involvement of microRNA Mir15a in control of human ovarian granulosa cell proliferation, apoptosis, steroidogenesis, and response to FSH. Microrna. 2014;3:29.

92. Amsterdam A, Kerental I, Aharoni D, Dantes A, Land-Bracha A, Rimon, Sasson R, Hirsh L. Steroidogenesis and apoptosis in the mammalian ovary. Steroids. 2003:68(10):861-7.

93. Zhang J, Liu Y, Yao W, Li Q, Liu HL, Pan Z. Initiation of follicular atresia: gene networks during early atresia in pig ovaries. Reproduction. 2018. https://doi. org/10.1530/REP-18-0058.

94. Ji DLY, Kim V, Muth DC, Witwer KW. Validated MicroRNA target databases: An evaluation. Drug Dev Res. 2015;76:389-96.

95. Tripurani SK, Xiao C, Salem M, Yao J. Cloning and analysis of fetal ovary microRNAs in cattle. Anim Reprod Sci. 2010;120:16-22.

96. Torley KJ, da Silveira JC, Smith P, Anthony RV, Veeramachaneni DNR, Winger QA, Bouma GJ. Expression of miRNAs in ovine fetal gonads: potential role in gonadal differentiation. Reprod Biol Endocrinol. 2011;9:2.

97. Ahn HW, Morin RD, Zhao H, Harris RA, Coarfa C, Chen Z-J, Milosavljevic A, Marra MA, Rajkovic A. MicroRNA transcriptome in the newborn mouse ovaries determined by massive parallel sequencing. Mol Hum Reprod. 2010; 16:463-71

98. Ro S, Song R, Park C, Zheng H, Sanders KM, Yan W. Cloning and expression profiling of small RNAs expressed in the mouse ovary. RNA. 2007:13:2366-80.

99. Mishima T, Takizawa T, Luo S-S, Ishibashi O, Kawahigashi Y, Mizuguchi Y, Ishikawa T, Mori M, Kanda T, Goto T, Takizawa T. MicroRNA (miRNA) cloning analysis reveals sex differences in miRNA expression profiles between adult mouse testis and ovary. Reproduction. 2008;136:811-22.

100. Hossain MM, Ghanem N, Hoelker M, Rings F, Phatsara C, Tholen E, Schellander $\mathrm{K}$, Tesfaye D. Identification and characterization of miRNAs expressed in the bovine ovary. BMC Genomics. 2009;10:443.
101. Huang J, Ju Z, Li Q, Hou Q, Wang C, Li J, Li R, Wang L, Sun T, Hang S, et al. Solexa sequencing of novel and differentially expressed microRNAs in testicular and ovarian tissues in Holstein cattle. Int J Biol Sci. 2011;7:1016-26.

102. Li M, Liu Y, Wang T, Guan J, Luo Z, Chen H, Wang X, Chen L, Ma J, Mu Z, et al. Repertoire of porcine microRNAs in adult ovary and testis by deep sequencing. Int J Biol Sci. 2011;7:1045-55.

103. Yang H, Lin S, Lei X, Yuan C, Tian Z, Yu Y, Zhao Z, Chen J. Identification and profiling of microRNAs from ovary of estrous Kazakh sheep induced by nutritional status in the anestrous season. Anim Reprod Sci. 2016;175:18.

104. Xu B, Zhang YW, Zheng SX, Tong XH, Liu YS. Expression profile of MicroRNAs and their targeted pathways in human ovaries detected by next-generation small RNA sequencing. DNA Cell Biol. 2016;35:226.

105. Furlong HC, Stämpfli MR, Gannon AM, Foster WG. Identification of microRNAs as potential markers of ovarian toxicity. J Appl Toxicol. 2018; 38(5):744-52.

106. Ling Y-H, Ren C-H, Guo X-F, Xu L-N, Huang Y-F, Luo J-C, Zhang Y-H, Zhang $X-R$, Zhang Z-J. Identification and characterization of microRNAs in the ovaries of multiple and uniparous goats (Capra hircus) during follicular phase. BMC Genomics. 2014;15:339.

107. Miles JR, McDaneld TG, Wiedmann RT, Cushman RA, Echternkamp SE, Vallet $J$, Smith TPL. MicroRNA expression profile in bovine cumulus-oocyte complexes: possible role of let-7 and miR-106a in the development of bovine oocytes. Anim Reprod Sci. 2012;130:16-26.

108. Xu Y-W, Wang B, Ding C-H, Li T, Gu F, Zhou C. Differentially expressed micoRNAs in human oocytes. J Assist Reprod Genet. 2011;28:559-66.

109. Xu B, Zhang Y-W, Tong X-H, Liu Y-S. Characterization of microRNA profile in human cumulus granulosa cells: identification of microRNAs that regulate notch signaling and are associated with PCOS. Mol Cell Endocrinol. 2015; 404:26-36.

110. Xie S, Batnasan E, Zhang Q, Li Y. MicroRNA expression is altered in granulosa cells of ovarian Hyperresponders. Reprod Sci. 2016;23:1001-10.

111. Hong L, Peng S, Li Y, Fang Y, Wang Q, Klausen C, Yin C, Wang S, Pck L, Yang X. MiR-106a increases granulosa cell viability and is down-regulated in women with diminished ovarian reserve. J Clin Endocrinol Metab. 2018; 103(6):2157-66.

112. Fiedler SD, Carletti MZ, Hong X, Christenson LK. Hormonal regulation of MicroRNA expression in periovulatory mouse mural granulosa cells. Biol Reprod. 2008:79:1030-7.

113. Sang Q, Yao Z, Wang H, Feng R, Wang H, Zhao X, Xing Q, Jin L, He L, Wu L, Wang $L$. Identification of microRNAs in human follicular fluid: characterization of microRNAs that govern steroidogenesis in vitro and are associated with polycystic ovary syndrome in vivo. J Clin Endocrinol Metab. 2013;98:3068-79.

114. Sørensen AE, Wissing ML, Englund AL, Dalgaard LT. MicroRNA species in follicular fluid associating with polycystic ovary syndrome and related intermediary phenotypes. J Clin Endocrinol Metab. 2016. https://doi.org/10. 1210/jc.2015-3588.

115. Santonocito M, Vento M, Guglielmino MR, Battaglia R, Wahlgren J, Ragusa M, Barbagallo D, Borzì P, Rizzari S, Maugeri M. Molecular characterization ofexosomes and their microRNA cargo in human follicular fluid: bioinformatic analysis reveals that exosomal microRNAs control pathways involved in follicular maturation. Fertil Steril. 2014;102:1751-1761.e1751.

116. Andrade GM, Meirelles FV, Perecin F, Silveira JD. Cellular and extracellular vesicular origins of miRNAs within the bovine ovarian follicle. Reprod Domest Anim. 2017. https://doi.org/10.1111/rda.13021.

117. Jiang L, Huang J, Chen Y, Yang Y, Li R, Li Y, Chen X, Yang D. Identification of several circulating microRNAs from a genome-wide circulating microRNA expression profile as potential biomarkers for impaired glucose metabolism in polycystic ovarian syndrome. Endocrine. 2016;53:280-90.

118. Peng JY, An XP, Fang F, Gao KX, Xin HY, Han P, Bao LJ, Ma HD, Cao BY. MicroRNA-10b suppresses goat granulosa cell proliferation by targeting brain-derived neurotropic factor. Domest Anim Endocrinol. 2016;54:60.

119. Carletti MZ, Fiedler SD, Christenson LK. MicroRNA 21 blocks apoptosis in mouse Periovulatory granulosa cells. Biol Reprod. 2010;83:286-95.

120. Fang $X, H u L$, Zhang $Y$, Xiao $X$, Xiao J. miR-22 inhibits mouse ovarian granulosa cell apoptosis by targeting SIRT1. Biology Open. 2016;5:367-71.

121. Yang $X$, Zhou Y, Peng S, Wu L, Lin HY, Wang S, Wang H. Differentially expressed plasma microRNAs in premature ovarian failure patients and the potential regulatory function of mir-23a in granulosa cell apoptosis. Reproduction. 2012;144:235. 
122. Liu J, Tu F, Yao W, Li X, Xie Z, Liu H, Li Q, Pan Z. Conserved miR-26b enhances ovarian granulosa cell apoptosis through HAS2-HA-CD44-Caspase3 pathway by targeting HAS2. Sci Rep. 2016;6:21197.

123. Tu F, Pan ZX, Yao Y, Liu HL, Liu SR, Xie Z, Li QF. miR-34a targets the inhibin beta $\mathrm{B}$ gene, promoting granulosa cell apoptosis in the porcine ovary. Genet Mol Res. 2014;13:2504-12.

124. Yuan XU, Zhang AL, Xiao G, Zhe Z, Chen ZM, Hao Z, Jia-Qi LI. p53 and NFkB regulate microRNA-34c expression in porcine ovarian granulosa cells. J Integr Agric. 2016;15:1816-24

125. Jiang L, Huang J, Li L, Chen Y, Chen X, Zhao X, Yang D. MicroRNA-93 promotes ovarian granulosa cells proliferation through targeting CDKN1A in polycystic ovarian syndrome. J Clin Endocrinol Metab. 2015;100:729-38.

126. Wang C, Li D, Zhang S, Xing Y, Gao Y, Wu J. MicroRNA-125a-5p induces mouse granulosa cell apoptosis by targeting signal transducer and activator of transcription 3. Menopause. 2016:23:100.

127. Du X, Li Q, Pan Z, Li Q. Androgen receptor and miRNA-126* axis controls follicle-stimulating hormone receptor expression in porcine ovarian granulosa cells. Reproduction. 2016;152:161.

128. Chen X, Xie M, Liu D, Shi K. Downregulation of microRNA-146a inhibits ovarian granulosa cell apoptosis by simultaneously targeting interleukin-1 receptor-associated kinase and tumor necrosis factor receptor-associated factor 6. Mol Med Rep. 2015;12:5155.

129. Yin M, Wang $X$, Yao G, Lu M, Liang M, Sun Y, Sun F. Transactivation of miR320 by miR-383 regulates granulosa cell functions by targeting E2F1 and SF-1 proteins. J Biol Chem. 2014;289:18239-57.

130. Toms D, Xu S, Bo P, Wu D, Li J. Progesterone receptor expression in granulosa cells is suppressed by microRNA-378-3p. Mol Cell Endocrinol. 2015;399:95-102.

131. Yin M, Lü M, Yao G, Tian H, Lian J, Liu L, Liang M, Wang Y, Sun F. Transactivation of microRNA-383 by steroidogenic factor-1 promotes estradiol release from mouse ovarian granulosa cells by targeting RBMS1. Mol Endocrinol. 2012;26:1129.

132. Marcy Maguire M. The miR-503/322/351 cluster mediates aging-dependent reduction of mitochondrial activity by targeting autophagy/ Mitophagy-associated genes in mouse ovarian granulosa cells; 2015.

Ready to submit your research? Choose BMC and benefit from:

- fast, convenient online submission

- thorough peer review by experienced researchers in your field

- rapid publication on acceptance

- support for research data, including large and complex data types

- gold Open Access which fosters wider collaboration and increased citations

- maximum visibility for your research: over $100 \mathrm{M}$ website views per year

At $\mathrm{BMC}$, research is always in progress.

Learn more biomedcentral.com/submissions 